\title{
Relationship between Selected Hydrochemical Parameters in Springs of Najaf Province, Iraq
}

\author{
Saadi A. M. Al-Dahaan1, Abdelkadhum J. Alabidi', Nadhir Al-Ansari², Sven Knutsson² \\ ${ }^{1}$ Department of Geology, Faculty of Science, University of Kufa, Kufa, Iraq \\ ${ }^{2}$ Department of Civil, Environmental and Natural Resources Engineering, Lulea University of Technology, \\ Lulea, Sweden \\ Email: nadhir.alansari@ltu.se
}

Received 25 May 2015; accepted 23 June 2015; published 26 June 2015

Copyright (C) 2015 by authors and Scientific Research Publishing Inc.

This work is licensed under the Creative Commons Attribution International License (CC BY).

http://creativecommons.org/licenses/by/4.0/

c) (i) Open Access

\section{Abstract}

Several springs exist at the south-western desert of Iraq in Najaf Province at latitude $31^{\circ} 00^{\prime}$ $32^{\circ} 15^{\prime}$ and longitude $43^{\circ} 30^{\prime}-44^{\circ} 30$ '. They are almost parallel to Euphrates River on the eastern edge of western desert. General direction for the distribution of springs coincides with that of faults running northwest-southeast. The Hydrogen sulfide, temperature, $\mathrm{pH}$ and electrical conductivity were investigated in these springs. The analyses indicated that the concentration of $\mathrm{H}_{2} \mathrm{~S}$ decreased from northwest toward southeast which is attributed to the escape of this gas to the atmosphere during the flow of groundwater near or on the earth surface. The surrounding geologic conditions did not affect the temperature and $\mathrm{pH}$ of the springs. Electrical conductivity showed an increase from northwest towards southeast which reflects dissolving more ions from the rocks of the aquifer. The electrical conductivity and hydrogen sulfide concentration had reverse relationship.

\section{Keywords}

Najaf, Springs, Electrical Conductivity, pH, Iraq

\section{Introduction}

Hydrogen sulfide is colorless, poisonous, annoying, and flammable gas, with a special rotten-egg-like odor detectable by humans at low concentrations with a sweet smelling at higher concentrations. It can be toxic, but its strong odor usually allows for detection long before it reaches high levels, but if the gas is released in a confined 
area it can cause nausea, illness, and in extreme situations even death [1]. $\mathrm{H}_{2} \mathrm{~S}$ named as hydrosulfuric acid, sulphuretted hydrogen, sewer gas, is naturally occurring in crude petroleum, volcanic gases, and hot springs. There are man-made sources of $\mathrm{H}_{2} \mathrm{~S}$ gas, such as food processing, coke ovens, paper manufacturing mills, solid waste disposal facilities, petroleum refineries, and waste water treatment plants. It is slightly heavier than air with specific gravity of 1.189 and may accumulate in the low-lying areas, enclosed, and the poorly ventilated [2]. Hydrogen Sulfide exists in environments of oxygen-deficient such as deep wells and plumbing systems. Sulfur-reducing bacteria SRB exist in groundwater and it uses sulfur for energy source and chemically change sulfates to produce $\mathrm{H}_{2} \mathrm{~S}$. These bacteria use the sulfur from decaying plants, rocks, or soil [3]. Hydrogen sulfide can exist naturally in groundwater as well. It can enter surface water through natural springs and quickly escape into the atmosphere and transforms into sulfuric acid $\mathrm{H}_{2} \mathrm{SO}_{4}$ or sulfur dioxide $\mathrm{SO}_{2}$ [4].

There is no quality standard of drinking water set for hydrogen sulfide in water, water supplies with 1ppm of hydrogen sulfide may be corrosive and tarnish copper and silverware [5]. Natural sources of hydrogen sulfide in water springs are due to the decomposing of underground deposits of organic matter such as decaying plant material and it can produce hydrogen sulfide. Wells drilled in shale or sandstone or near coal or oil fields may be sources of hydrogen sulfide and the Sulfur-reducing bacteria feed on the naturally occurring sulfates in water, producing hydrogen sulfide gas as a by-product [6].

Most of the water in Iraq is consumed for irrigation purposes [7]-[10]. The agricultural practices are restricted to a narrow strip along the Euphrates and Tigris River and the groundwater use for irrigation is limited. Now, Iraq is experiencing water shortage crisis due to the high number of dams on the Tigris and Euphrates and their tributaries outside Iraq, the effect of global climate change, and mismanagement of water resources [7]-[10]. To overcome this crisis, requires that other resources be used like groundwater wells and springs to overcome this problem [8]. Groundwater use is estimated about 12 billion cubic meters [11]. About 50\% of the groundwater is consumed for domestic purposes. This amount represents just $20 \%$ of the available resources that has been exploited [12]. Hand-dug wells are usually used in Iraq for domestic long time ago. Hydrogeological investigation indicates that, there are 14 main aquifer groups available in Iraq divided into five hydrological units [13].

In this research, springs located in area which is in the south western part of Iraq in Najaf Province at latitude $31^{\circ} 00^{\prime}-32^{\circ} 15^{\prime}$ and longitude $43^{\circ} 30^{\prime}-44^{\circ} 30^{\prime}$ had been investigated to find out their concentrations of Hydrogen sulfide, Temperature, $\mathrm{pH}$ and Electrical conductivity (Figure 1). Najaf springs are one of series springs that extend from Hit city at Al-Anbar Province in the west of Iraq to Samawa city at Al-Mothanna Province in south western part of Iraq. They are almost parallel to Euphrates River on the eastern edge of western desert. General direction for the distribution of springs coincides with that of faults running northwest-southeast [14]-[18]. Water supplied from springs is of more importance in Iraq now especially in region where surface water is scarce.

\section{Geology and Stratigraphy}

The exposed rocks within the study area are sedimentary rocks of upper Cretaceous and Quaternary period (Figure 1) [14] [16]. In the western desert, there are many faults with two main directions. The first, are deep primary faults trending northeast-southwest with some of complementary faults trending northwest-southeast. The second set of faults is deeper trending north-south and east-west. The distribution of springs takes a northsouth trend. The study area of the springs is located in a depression referred to "Bahar-Al-Najaf" and they are bounded from the north by steep slope cliffs. Surface of study area is covered by the sand dunes, alluvium and cliff wall. Dammam formation outcrops at the western side of the study area, while the Euphrates formation uncomfortably overlies Dammam followed by conformable contact with Dibdiba formation. The sequence, age, lithology, thickness and depth of each formation are listed in Table 1 [12].

\section{Hydrogeology}

There are two aquifers within the study area. The first is composed of recent deposits (mainly mud or clay, silt and sand pebbles), while the second aquifer is of Miocene deposits (Dibdiba, Fatha and Euphrates Formations). The aquifer is mainly composed of pebbly sandstone and sandstone with some clay stones, siltstones and marl associated with secondary gypsum. These deposits contain more significant quantity of groundwater under hydrostatic pressure (confined aquifer) compared to recent deposits. In view of this situation, groundwater flow naturally upward to the surface of the ground forming these springs [19]. A huge gentle anticline exists in this 


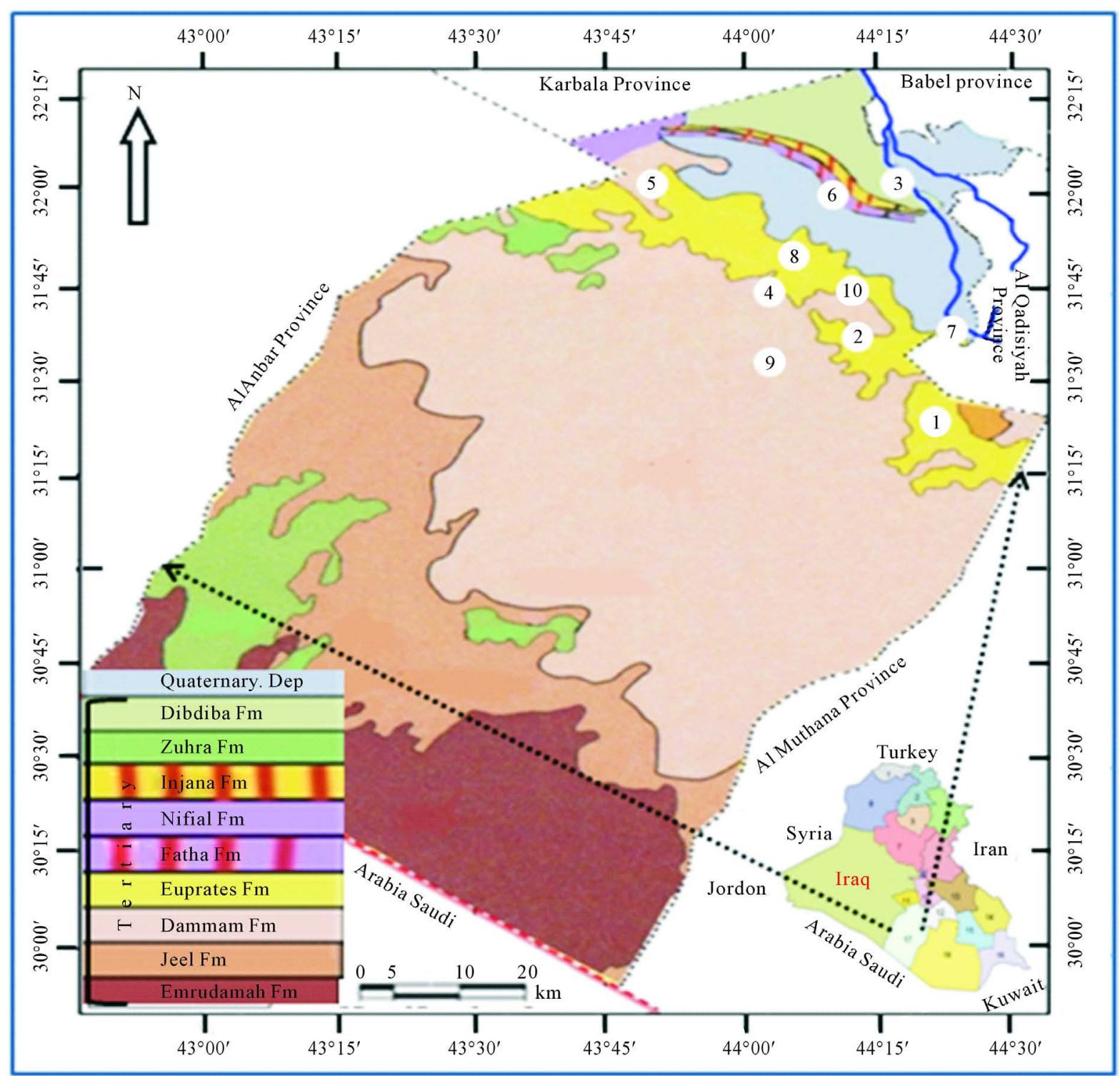

Figure 1. Locations and geologic map for springs at study area.

Table 1. Stratigraphic Section for Al-Kifl well No. 1 at study area.

\begin{tabular}{|c|c|c|c|c|}
\hline Formation & Age & Lithology & Thickness M & Depth M \\
\hline $\begin{array}{l}\text { Soil and alluvial deposits } \\
\text { and Dibdiba fm }\end{array}$ & $\begin{array}{l}\text { Pleistocene } \\
\text { U. Miocene }\end{array}$ & friable sand gravel, Sand, feldspar and marl & 93.5 & 93.5 \\
\hline Fatha & M. Miocene & Gypsum, silty gypsum, lime clay and limestone & 106.4 & 197 \\
\hline Euphrates & L. Miocene & Fine grains limestone with lime clay & 43.6 & 303.4 \\
\hline Dammam & U. Eocene & $\begin{array}{l}\text { Fine grains of dolomitic limestone and lime clay } \\
\text { at lower part }\end{array}$ & 189.9 & 374 \\
\hline Rus & L. Eocene & Limestone with fine grains of anhydrite and dolomite & 73.6 & 536.9 \\
\hline Al-Alegy & L. Eocene Paleocene & Lime clay, limestone and dolomite & 271.9 & 610.5 \\
\hline Shiranish & U. Cretaceous & Lime clay containing a cutting of limestone & 67.3 & 882.4 \\
\hline
\end{tabular}


area and it covers the eastern part of western-southern deserts. The study area lies on the northern part of this anticline. The recharge area is located north of this anticlinal area while the discharge area is where the springs exist over the confined aquifers [14].

\section{Materials and Methods}

Ten samples of water springs were collected from the studied area during January, 2015. Temperature, $\mathrm{pH}$ and electrical conductivity "EC" were directly measured in the field. The scan spectrolyser measures the attenuation of light in the UV-VIS spectrum between 200 and $750 \mathrm{~nm}$ was used to find the concentrations of hydrogen sulfide [5]. The result of the analysis is tabulated in Table 2. [20]:

To calculate the range and average of E.C, $\mathrm{pH}$, Temp and $\mathrm{H}_{2} \mathrm{~S}$ the following equation was used (Table 2)

$$
R R=\frac{\Delta R}{\max -R} \times 100
$$

whereas:

$R R=$ Rang Variation Ratio.

$\Delta R=$ Difference between upper and lower limit.

$\max -R=$ Upper limit.

According to above equation, range variation ratio was divided into three types:

1) Not significant, when the variation test is between $1 \%-5 \%$.

2) Probably significant, when the variation is between $5 \%-10 \%$.

3) Highly significant, when the variation is more than $10 \%$.

\section{Result and Discussion}

\subsection{Accuracy of Analysis}

Accuracy of water analysis was calculated by double test for two random of water springs (2-Maatook spring, 8-Assawed Sprig), using standard deviation method [20]. The temperature of water was measured in the field only. The result of standard deviation for $\mathrm{H}_{2} \mathrm{~S}$, E.C and $\mathrm{pH}$ were between $0.14-1.41 / 1000$ which reflects good accuracy for the function of chemical analysis as shown in Table 3.

Table 2. E.C, $\mathrm{pH}$, Tem and $\mathrm{H}_{2} \mathrm{~S}$ in water springs.

\begin{tabular}{|c|c|c|c|c|c|c|c|c|c|}
\hline \multirow{3}{*}{$\begin{array}{c}\text { No. } \\
1\end{array}$} & \multirow{3}{*}{$\begin{array}{c}\text { Name of Springs } \\
\text { Staah }\end{array}$} & \multirow{3}{*}{$\begin{array}{c}\text { E.C m. mhos/cm } \\
2.41\end{array}$} & \multirow{3}{*}{$\begin{array}{l}\mathrm{pH} \\
6.9\end{array}$} & \multirow{3}{*}{$\frac{\mathrm{Tem}{ }^{\circ} \mathrm{C}}{24}$} & \multirow{3}{*}{$\begin{array}{c}\mathrm{H}_{2} \mathrm{~S} p \mathrm{ppm} \\
24\end{array}$} & \multicolumn{4}{|c|}{ Location } \\
\hline & & & & & & \multicolumn{2}{|c|}{ Longitude } & \multicolumn{2}{|c|}{ Latitude } \\
\hline & & & & & & 31 & 22 & 44 & 19 \\
\hline 2 & Maatook & 2.24 & 6.9 & 23.5 & 41 & 31 & 37 & 44 & 12 \\
\hline 3 & Jaain & 2.27 & 6.9 & 24.5 & 59 & 31 & 56 & 44 & 14 \\
\hline 4 & Rohban & 1.91 & 7.0 & 23 & 78 & 31 & 44 & 44 & 01 \\
\hline 5 & Haiadea & 1.82 & 6.9 & 23.5 & 95 & 32 & 03 & 43 & 49 \\
\hline 6 & Rehamiah & 1.97 & 6.9 & 24 & 75 & 31 & 57 & 44 & 07 \\
\hline 7 & Iszia & 2.33 & 6.9 & 23.5 & 37 & 31 & 38 & 44 & 23 \\
\hline 8 & Assawed & 1.86 & 7.1 & 23 & 80 & 31 & 51 & 44 & 04 \\
\hline 9 & Rahba & 2.16 & 6.9 & 23.5 & 63 & 31 & 34 & 44 & 02 \\
\hline \multirow[t]{3}{*}{10} & Ruiez & 2.08 & 6.9 & 23.5 & 71 & 31 & 44 & 44 & 22 \\
\hline & Range & $1.82-2.41$ & $6.9-7.1$ & $23-24.5$ & $24-95$ & & & & \\
\hline & Average & 2.11 & 6.93 & 23.6 & 62.3 & & & & \\
\hline
\end{tabular}


Table 3. Accuracy of analysis for two random of water springs.

\begin{tabular}{ccccccc}
\hline Variables & 2-Maatook & Average & Standard deviation & 8-Assawed & Average & Standard deviation \\
\hline $\mathrm{H}_{2} \mathrm{~S}$ ppm & $40-41$ & 40.5 & 0.71 & $80-79$ & 79.5 & 0.71 \\
E.C m. mhos/cm & $2.22-2.24$ & 2.23 & 0.14 & $2.53-2.48$ & 0.22 & 1.41 \\
$\mathrm{pH}$ & $6.9-6-9$ & 6.9 & 0 & $7.1-7.1$ & 7.1 & 0 \\
\hline
\end{tabular}

\subsection{Temperature and $\mathrm{pH}$}

Groundwater systems whether local or regional are usually heterogeneous and respond in a highly non-linear manner to changes in climate. They are commonly characterized by their relatively slow response to environmental change compared with surface water because of their large storage capacity [21]. Groundwater temperature varies with depth and it is a function of two main factors: first, the geothermal gradient, and second, the ambient temperature at the land surface [22].

Separating what may be relatively small climate change signals from these other environmental change signals in groundwater systems is proving to be highly challenging [23]. When the groundwater flow is absence, the subsurface temperature commonly follows the geothermal gradient (typically an increase of $1^{\circ} \mathrm{C}$ per about 20 - 40 meters of depth) [24]. Within the geothermal zone the temperature profile is not subject to seasonal variations and typically increases linearly with depth except where perturbed by groundwater flow or changes in thermal conductivity of the matrix. Within surface or near the surface zone, temperature may be influenced by the seasonal heating and cooling of the land surface. Shallow groundwater temperature is generally $1^{\circ} \mathrm{C}-2^{\circ} \mathrm{C}$ higher or less than the mean annual surface temperature [2]. At study area, the temperature of water sprigs which is measured in the field was between $23-24.5$ with an average of $23.6^{\circ} \mathrm{C}$. These values of temperature show significant change (6.1\%) [20]. On the other hand, the temperature of atmosphere during the collection of water samples during January was between 9 in the morning and $17^{\circ} \mathrm{C}$ during midday. This leads to believe that the temperature of the atmosphere is slightly affecting the temperature of the water of the springs [2]. According to this and the fact that no geothermal activity had been recorded at the present period the temperature values of water springs were as it was recorded in Table 2.

The $\mathrm{pH}$ of a solution is defined as the negative logarithm of its hydrogen ion activity [25].

$\mathrm{pH}=-\log [\mathrm{H}+]$. The technical definition for $\mathrm{pH}$ is that it is a measure of the activity of the hydrogen ion $(\mathrm{H}+)$ and is reported as the reciprocal of the logarithm of the hydrogen ion activity. Therefore, a water with a $\mathrm{pH}$ of 7 has 10 - 7 moles per liter of hydrogen ions; whereas, a $\mathrm{pH}$ of 6 is $10-6$ moles per liter. The $\mathrm{pH}$ scale ranges from 0 - 14. In general, water with a $\mathrm{pH}<7$ is considered acidic and if $\mathrm{pH}=7$ then it is neutral while if it is $\mathrm{pH}>7$ then it is considered as basic. The normal range for $\mathrm{pH}$ in surface water systems is $6.5-8.5$ and for groundwater systems is 6 - 8.5 [26]. The $\mathrm{pH}$ range for the springs at the studied area was between 6.9 to 7.1 and the average was 6.93. All the springs have not significant change $2.8 \%$ [20], and the values of $\mathrm{pH}$ for all springs were within the normal limit.

Pure water has a $\mathrm{pH}$ of exactly 7 at $25^{\circ} \mathrm{C}$. As the water temperature increases, $\mathrm{pH}$ decreases and vice versa, i.e. colder water has a higher $\mathrm{pH}$ value. At $60^{\circ} \mathrm{C}$ pure water has a $\mathrm{pH}$ value of 6.96 . Thus, the change is very slight and cannot be registered with crude measurement techniques such as $\mathrm{pH}$ test strips. The reason that temperature affects $\mathrm{pH}$ in water is that water molecules have a slight tendency to break down into their constituents, hydrogen and oxygen, as temperature increases. When temperatures increase, a larger proportion of water molecules break up, releasing more hydrogen ions, which then causes the decreases of $\mathrm{pH}$ and vice versa [27]. When $\mathrm{pH}$ is measured at room temperature, there is no direct correlation between $\mathrm{pH}$ and temperature [28]. The difference between the range of temperature and $\mathrm{pH}$ for water springs is nearly approaching room temperature and neutral point of water respectively (Table 2), so that there is no direct influence of temperature on $\mathrm{pH}$ for the water springs.

\subsection{Electrical Conductivity (EC) and Temperature}

Electrical conductivity is an indirect measurement of salinity, and it is temperature dependent [29]. The response of the conductance value to temperature changes is somewhat different for different salts and different concentrations, but in dilute solutions for most ions, an increase of $1^{\circ} \mathrm{C}$, increases conductance by about $0.5 \%-1 \%$. It 
also increases with the increase of the total dissolved solids [3]. Groundwater conductance is a function of temperature, type of present ions and the types of dissolved constituents [25]. The relationship between EC and temperature for natural waters is generally nonlinear [30]. However, the degree of nonlinearity is relatively small in a temperature range of environmental monitoring $\left(0^{\circ} \mathrm{C}-30^{\circ} \mathrm{C}\right)$. The linear equation, below is commonly used to represent the relation between EC and temperature [30].

$$
\mathrm{ECt}=\mathrm{EC} 25[1+\mathrm{a}(\mathrm{t}-25)]
$$

where ECt is electrical conductivity at temperature t $\left({ }^{\circ} \mathrm{C}\right)$, EC25 is electrical conductivity at $25^{\circ} \mathrm{C}$, and a $\left({ }^{\circ} \mathrm{C}-1\right)$ is a temperature compensation factor. Many values are cited in the standard literature. For example, ([31], pp. 2-47) recommended that $\mathrm{a}=0.0191$, based on the EC-temperature relationship of $0.01 \mathrm{M}$ of $\mathrm{KCl}$ solution. Groundwater textbooks frequently cite $2 \%$ increase of EC per $1^{\circ} \mathrm{C}$ increase of temperature ([6], p. 71, [29], p. 67), which can be translated to $\mathrm{a}=0.02$, while geophysicists commonly use $\mathrm{a}=0.025$ ([32], p. 31). The spatial distribution of EC is controlled by several factors and practices, which may cause salinity variation within the study area. Some of these factors are the depth of aquifers, rock type leaching, long term discharge with high rates of recharge and the distance between recharge and discharge [12]).

At study area electrical conductivity of water springs was between $1.83-2.41 \mathrm{~m}$. mhos/cm. It has highly significant change of $24.1 \%$ (Figure 2) with probably significant change in the temperature [20]. The change in the EC is observed from Haiadea spring number $5(E C=1.82)$ toward Staah spring number $1(E C=2.41)$ (Figure 1), or in other words, the increase trend of EC is from northwest towards southeast for a distant of about 62 kilometers. It reflects an increase of total dissolved solids in the water springs by dissolving more ions from the Dibdiba, Fatha and Soil, and alluvial Pleistocene aquifer formations through the migration of groundwater (Figure 3). This migration of groundwater at the study area corresponds with the general direction of groundwater at the western desert of Iraq [33].

\subsection{Electrical Conductivity (EC) and Hydrogen Sulfide}

EC is the ability for $1 \mathrm{~cm}^{3}$ of water to connect electric current at $25^{\circ} \mathrm{C}$ [34]. It is a mark of ions type, temperature and dissolved constituents type [26]. Hydrogen sulfide solubility limit in the water is relatively high, with an equilibrium concentration of $4132 \mathrm{ppm}$ at $20^{\circ} \mathrm{C}$ [35]. The range of $\mathrm{H}_{2} \mathrm{~S}$ in the water springs is $24-95 \mathrm{ppm}$. The concentration of $\mathrm{H}_{2} \mathrm{~S}$ has very high significant changes 74.7\% [20]. $\mathrm{H}_{2} \mathrm{~S}$ originates from Sulfur-reducing bacteria that exist in groundwater where it uses sulfur as an energy source and chemically change sulfates to produce $\mathrm{H}_{2} \mathrm{~S}$ as in mentioned by [36].

In the study area, the origin of sulphates is the leaching of anhydrite in Rus formation (thickness $73.6 \mathrm{~m}$ at depth of $536.9 \mathrm{~m}$ ) and gypsum in Fatha formation (thickness $106.4 \mathrm{~m}$ and at depth of $197 \mathrm{~m}$ ) (Table 1). In addition,

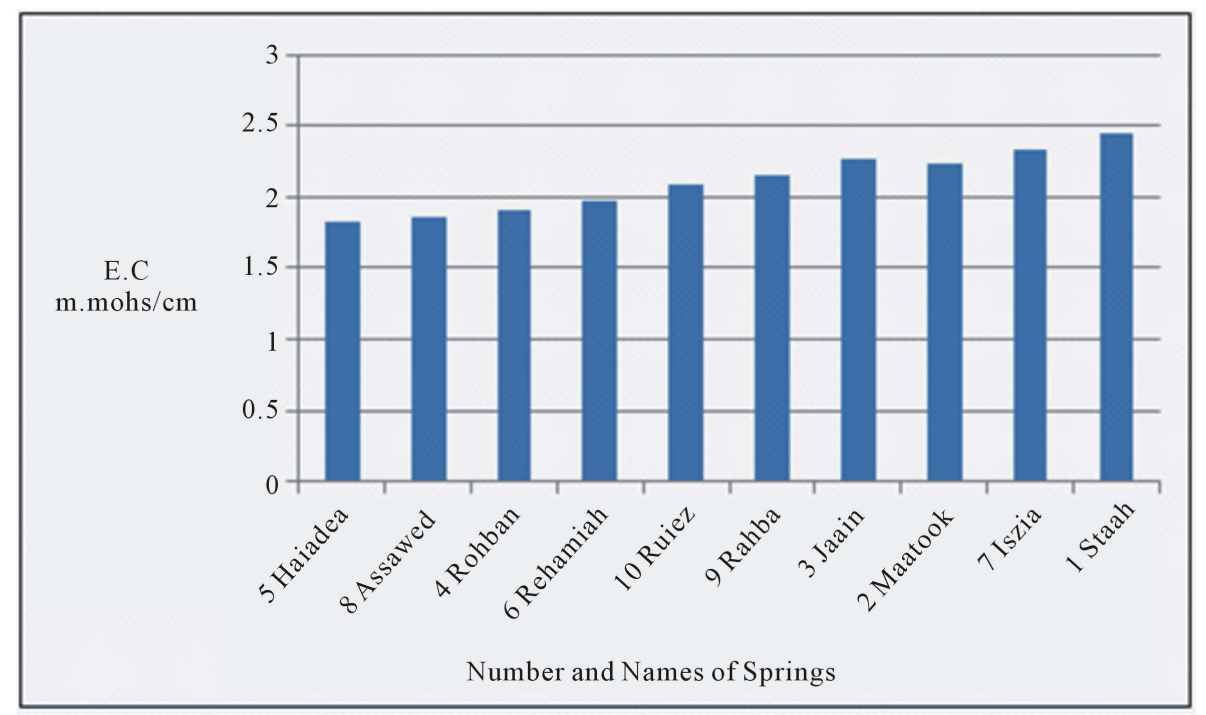

Figure 2. E.C for the water springs at study area. 


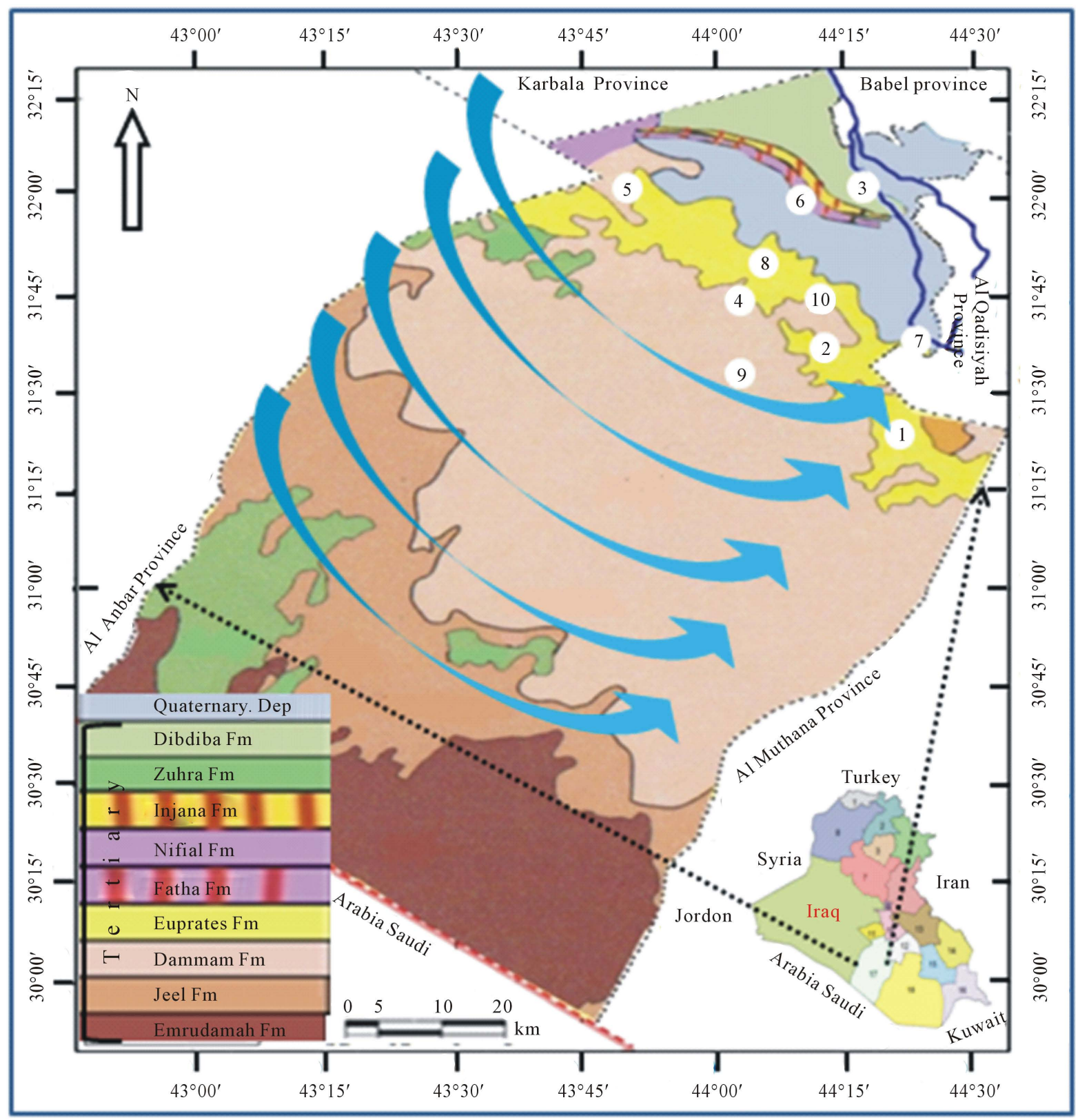

Figure 3. Migration of groundwater at study area.

most of the water of the springs (70\%) is of marine origin where $\mathrm{CaCl}_{2}$ is prevailing, while the other (30\%) are of continental origin where $\mathrm{Na}_{2} \mathrm{SO}_{4}$ is prevailing [12]. The decrease in the concentration of $\mathrm{H}_{2} \mathrm{~S}$ is clear from Haiadea spring number $5\left(\mathrm{H}_{2} \mathrm{~S}=95 \mathrm{ppm}\right)$ in the northwest toward Staah spring number $1\left(\mathrm{H}_{2} \mathrm{~S}=24 \mathrm{ppm}\right)$ in the southeast opposite to the change of EC (Figure 4). This might be due to the increase of EC from the northwest toward southeast is substituted by the decrease in $\mathrm{H}_{2} \mathrm{~S}$ (Figure 1). The decrease of $\mathrm{H}_{2} \mathrm{~S}$ toward southeast is attributed to the escape of $\mathrm{H}_{2} \mathrm{~S}$ to the atmosphere during the flow of groundwater near or on the earth surface [4]. The relationship between electrical conductivity and the concentration of hydrogen sulfide for the water of the springs at the study area is reverse relationship (Figure 5).

\section{Conclusion}

The distribution of the springs at Najaf province corresponds to the faults in the study area. The atmosphere 


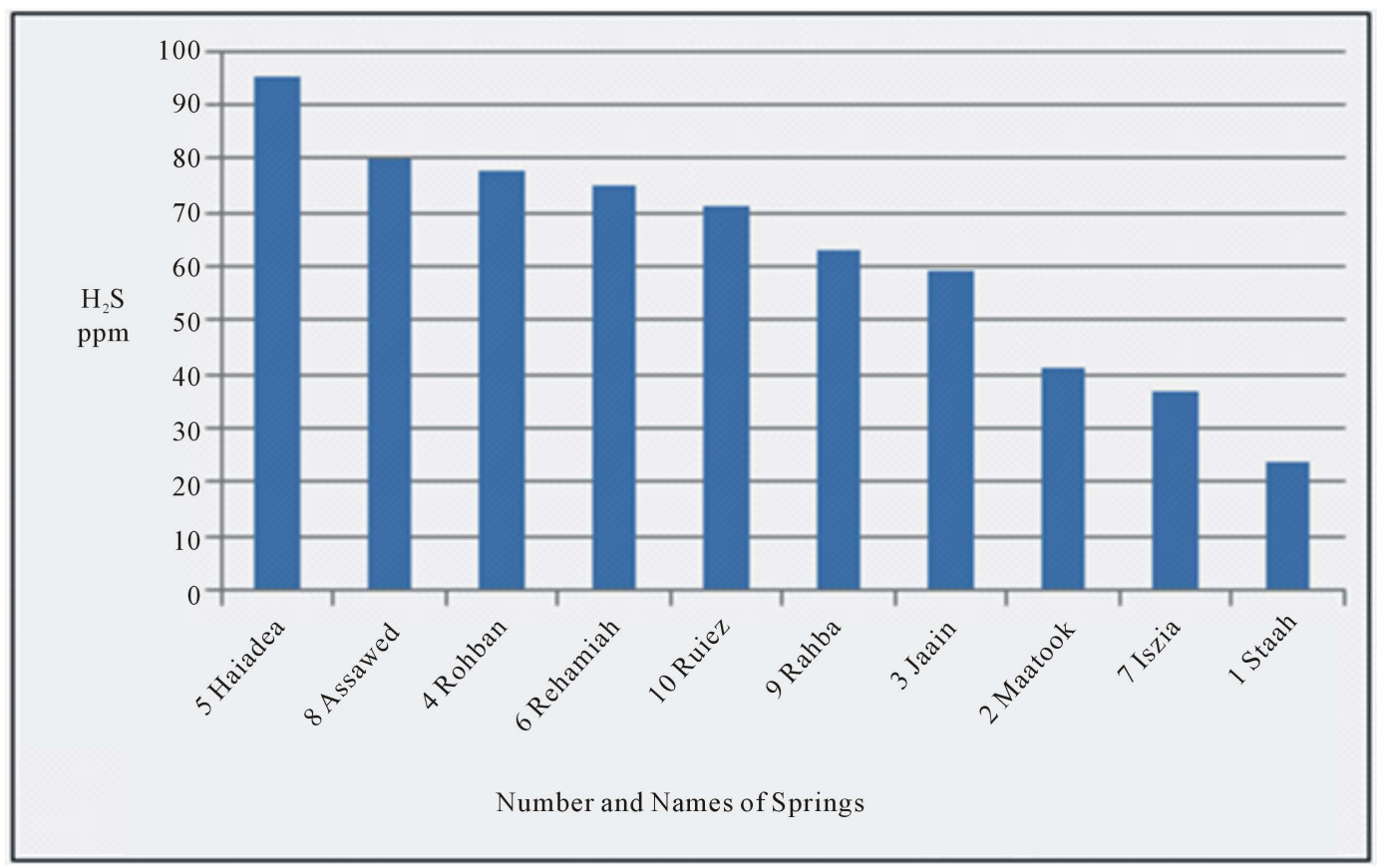

Figure 4. Hydrogen sulfide for the water springs at study area.

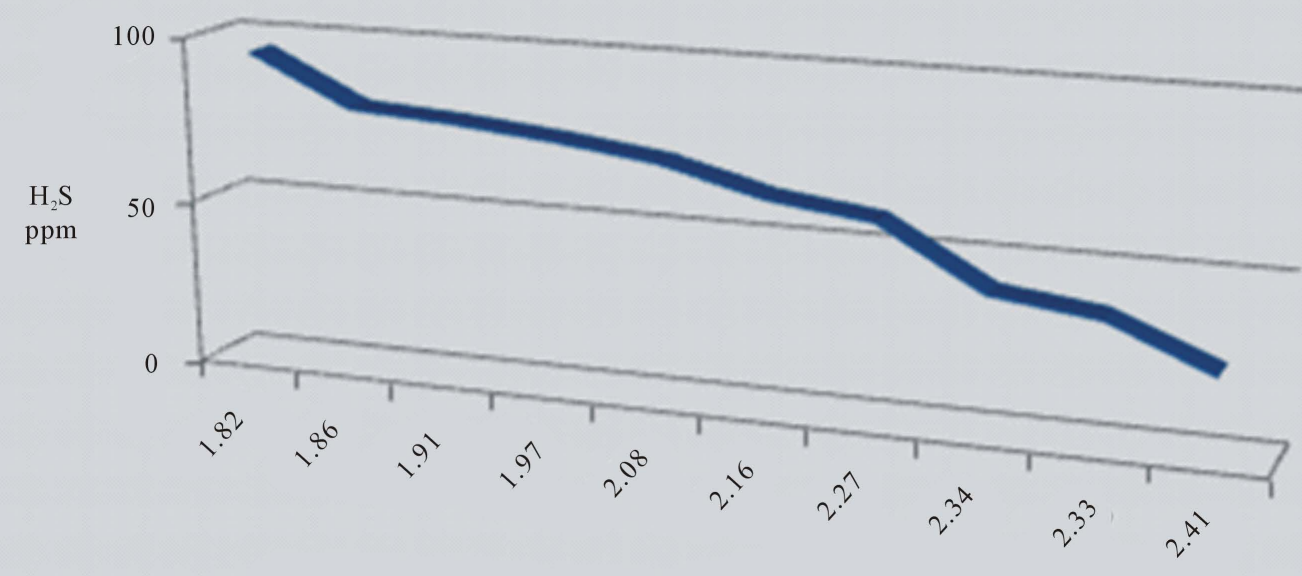

Electrical Conductivity $\mathrm{m}$. Mhos/cm

Figure 5. Reverse relation between E.C and $\mathrm{H}_{2} \mathrm{~S}$.

temperature is not affecting the temperature of the water of the springs. The $\mathrm{pH}$ values of the springs were within the normal limit and no direct influence between temperature and $\mathrm{pH}$ was noticed. The migration of groundwater at study area is similar to the general direction of groundwater at western desert of Iraq. It reflects an increase of total dissolved solids in the water springs by dissolving more ions from the rock of aquifer. $\mathrm{H}_{2} \mathrm{~S}$ is originated from Sulfur-reducing bacteria that exists in groundwater and uses sulfur as an energy source and it chemically changes sulfates to produce $\mathrm{H}_{2} \mathrm{~S}$. The relation between EC and $\mathrm{H}_{2} \mathrm{~S}$ is reverse.

\section{Acknowledgements}

The authors would like to thank all the colloquies at the Department of Geology, University of Kufa for their fruitful suggestions and discussions. The research presented was supported financially by Luleå University of 
Technology, Sweden and by the "Swedish Hydropower Centre-SVC" established by the Swedish Energy Agency, Elforsk and Svenska Kraftnät together with Luleå University of Technology, The Royal Institute of Technology, Chalmers University of Technology and Uppsala University. This support is gratefully acknowledged.

\section{References}

[1] Guenther, E.A., Hohnson, K.S. and Coale, K.H. (2001) Direct Ultraviolet Spectrophotometric Determination of Total Sulfide and Iodide in Natural Waters. Analytical Chemistry, 73, 3481-3487. http://dx.doi.org/10.1021/ac0013812

[2] Busby, J., Lewis, M., Reeves, H. and Lawley, R. (2009) Initial Geological Considerations before Installing Ground Source Heat Pump Systems. Quarterly Journal of Engineering Geology and Hydrogeology, 42, 295-306. http://dx.doi.org/10.1144/1470-9236/08-092

[3] Detay, M. (1997) Water Wells-Implementation, Maintenance and Restoration. John Wiley and Sons, London, 379 p.

[4] Arnell, N.W. (1998) Climate Change and Water Resources in Britain. Journal of Climatic Change, 39, 83-110. http://dx.doi.org/10.1023/A:1005339412565

[5] Goldhaber, M.B. and Kaplan, I.R. (1975) Apparent Dissociation Constants of Hydrogen Sulfide in Chloride Solutions. Marine Chemistry, 3, 83-104. http://dx.doi.org/10.1016/0304-4203(75)90016-X

[6] Matthess, G. (1982) The Properties of Groundwater. John Wiley \& Sons, New York.

[7] Al-Ansari, N.A. and Knutsson, S. (2011) Toward Prudent Management of Water Resources in Iraq. Journal of Advanced Science and Engineering Research, 1, 53-67.

[8] Al-Ansari, N.A. (2013) Management of Water Resources in Iraq: Perspectives and Prognoses. Journal of Engineering, 5, 667-684. http://dx.doi.org/10.4236/eng.2013.58080

[9] Al-Ansari, N.A., Ali, A. and Knutsson, S. (2014) Present Conditions and Future Challenges of Water Resources Problems in Iraq. Journal of Water Resources and Protection, 6, 1066-1098. http://dx.doi.org/10.4236/jwarp.2014.612102

[10] Al-Ansari, N.A., Ali, A.A. and Knutsson, S. (2015) Iraq Water Resources Planning: Perspectives and Prognoses. ICCCE 2015: XIII International Conference on Civil and Construction Engineering, Jeddah, 26-27 January 2015, 2097-2108.

[11] Alsam, S., Jassim, S.Z. and Hanna, F. (1990) Water Balance of Iraq: Stage 2, Geological and Hydrogeological Conditions. Report, Ministry of Irrigation, Iraq.

[12] Al-Dahaan, S., Hussain, H., Al-Ansari, N. and Knutsson, S. (2015) Hydrochemistry of Springs, Najaf Area, Iraq. Journal of Environmental Hydrology, 23.

[13] Krasny, J., Alsam, S. and Jassim, S.Z. (2006) Hydrogeology. In: Jassim, S.Z. and Goff, J.C., Eds., Geology of Iraq, Dolin, Prague and Moravian Museum, Prague.

[14] Budy, T. and Jassim, S.Z. (1987) The Regional Geology of Iraq (Tectonism, Magmatism and Metamorphism). Report Submitted to the Iraqi Geological Survey, 325 p.

[15] Fouad, S.F. (2007) Tectonic and Structural Evolution of the Iraqi Western Desert. Geology of Iraqi Western Desert, Iraqi Bulletin of Geology and Mining, Special Issue No. 1, 29-50.

[16] Al-Juburi, H.K. and Al-Basrawi, N.H. (2007) Hydrogeology. Geology of Iraqi Western Desert, Special Issue of Iraqi Bulletin of Geology and Mining, 125-144.

[17] Al-Juburi, H.K. and Al-Basrawi, N.H. (2009) Hydrogeology. Geology of Iraqi Southern Desert, Special Issue of Iraqi Bulletin of Geology and Mining, 77-92.

[18] Ma’ala, K.A. (2009) Tectonic and Structural Evolution. Geology of Iraqi Southern Desert, Special Issue of Iraqi Bulletin of Geology and Mining, 35-52.

[19] Hassan, A.H. (1973) Hydrological, Hydrogeological and Hydrogeochemical Investigations of Bahar Al-Najaf Area. Unpublished Master's Thesis, University of Baghdad, Baghdad.

[20] Al-Sinawi, S. and Hassan, H. (1982) Computer Applications in Earth Science. Rafidan Press, Iraq, 404 p.

[21] Price, M. (1998) Water Storage and Climate Change in Great Britain-The Role of Groundwater. Proceedings of the Institute of Civil Engineers Water, Water Maritime and Energy, 130, 42-50.

[22] Stuart, M.E., Jackson, C.R. and Bloomfield, J.P. (2010) Preliminary Analysis of Trends in UK Groundwater Temperature Measurements from England and Wales. British Geological Survey Internal Report IR/10/033.

[23] Green, T.R., Taniguchi, M., Kooi, H., Gurdak, J.J., Allen, D.M., Hiscock, K.M., Treidel, H. and Aureli, A. (2011) Beneath the Surface of Global Change: Impacts of Climate Change on Groundwater. Journal of Hydrology, 405, 532-560. http://dx.doi.org/10.1016/j.jhydrol.2011.05.002 
[24] Anderson, M.P. (2005) Heat as a Groundwater Tracer. Ground Water, 43, 951-968. http://dx.doi.org/10.1111/j.1745-6584.2005.00052.x

[25] Boyed, C.E. (2000) Water Quality: An Introduction. Kluwer Academic Publisher, New York, 330 p.

[26] USGS, Groundwater Quality, 2010. http://water.usgs.gov/ogw/data.html

[27] Holman, I.P., Allen, D.M., Cuthbert, M.A. and Goderniaux, P. (2012) Towards Best Practice for Assessing the Impacts of Climate Change on Groundwater. Hydrogeology Journal, 20, 1-4. http://dx.doi.org/10.1007/s10040-011-0805-3

[28] Taylor, C.A. and Stefan, H.G. (2009) Shallow Groundwater Temperature Response to Climate Change and Urbanization. Journal of Hydrology, 375, 601-612. http://dx.doi.org/10.1016/j.jhydrol.2009.07.009

[29] Hem, J.D. (1985) Study and Interpretation of the Chemical Characteristics of Natural Water. 3rd Edition, US Geological Survey Water-Supply Paper 2254, 246 p.

[30] Sorensen, J.A. and Glass, G.E. (1987) Ion and Temperature Dependence of Electrical Conductance for Natural Waters. Analytical Chemistry, 59, 1594-1597. http://dx.doi.org/10.1021/ac00140a003

[31] Clesceri, L.S., Greenberg, A.E. and Eaton, A.D. (1998) Standard Methods for the Examination of Water and Wastewater. 20th Edition, American Public Health Association, Washington DC.

[32] Keller, G.V. and Frischknecht, F.C. (1966) Electrical Methods in Geophysical Prospecting. Pargamon Press, Oxford.

[33] Al-Fatlawi, A.N. (2010) Hydrogeological Study for Umm Er Radhuma Aquifer-West of Iraq. Unpublished Ph.D. Thesis, Baghdad University, Baghdad.

[34] Todd, D.K. (2007) Groundwater Hydrology. Second Edition, John Wiley and Sons, Inc., India.

[35] WHO, World Health Organization (2003) Hydrogen Sulfide: Human Health Aspects. Concise International Chemical Assessment Document 53.

[36] Zobell, G. (1963) Organic Geichemistry. Longmans, London, 392 p. 